\title{
Traditional Ecological Knowledge as a tool for biocultural landscape restoration in northern Veracruz, Mexico: a case study in El Tajín region
}

\author{
$\underline{\text { Noé Velázquez-Rosas }}^{1}, \underline{\text { Evodia Silva-Rivera }}^{1}$, Betsabé Ruiz-Guerra $^{2}$, Samaria Armenta-Montero $^{1}$ and Jesús Trejo González $^{3}$
}

\begin{abstract}
Zuelania guidonia is a tree species of cultural importance in Totonac society. This tree is a central element of the Los Voladores (the "flying men") pre-Hispanic ritual ceremony. However, the populations of Z. guidonia have decreased due to anthropogenic activity. This study aimed to codesign an agroforestry model for the recovery of $Z$. guidonia populations by combining scientific and traditional agroforestry knowledge at the El Tajín archaeological site in Veracruz, Mexico. We assessed the abundance of $Z$. guidonia and analyzed plant species richness and diversity in forest fragments. Species were classified according to plant regeneration modes (light-demanding and shade-tolerant) and to the local uses of secondary forests and conserved forest fragments. In addition, we worked collaboratively in a project that consisted of workshops, focus groups, open interviews, drawings, and field walks with community members. We studied a small population of Z. guidonia and recorded 116 woody species. Our findings showed that conserved forests were more diverse than secondary forests. Seventy-four percent of the species are useful to people. The Totonac people chose traditional vanilla plantations as a guiding model to shape their agroforestry system for restoring native vegetation. The results of our collaborative work revealed the Totonac extensive Traditional Ecological Knowledge and the need for the Voladores' group to strengthen alliances with other government and nongovernment organizations. They designed a model of a diversified traditional agroforestry vanilla system enriched with multipurpose plants as the outset of local well-being and regional agrobiodiversity restoration. This study reveals a distinct heterogenous land management scheme that provides the necessary conditions for preserving plant diversity, which will be used by local people for different purposes. We argue for studies that build on the relationship between scientific knowledge and Traditional Ecological Knowledge in transformed landscapes as a step forward for the long-term conservation of biocultural diversity.
\end{abstract}

Key Words: cultural landscapes; restoration; Totonac culture; useful plants; vanilla plantations; Zuelania guidonia

\section{INTRODUCTION}

The social-ecological crisis posed by global environmental change demands rethinking the ways in which we as humans relate with each other and other living beings at many levels and dimensions. Confronting these challenges requires different approaches to understanding the cultural, social, and economic drivers of environmental change (Anderson and Barbour 2003, Hobbs et al. 2011, Uprety et al. 2012, Mantyka-Pringle et al. 2017). Against this backdrop, Traditional Ecological Knowledge(TEK) has been increasingly recognized as a highly relevant approach to landscape management with the aim of sustainable use and natural resource conservation (Covington et al. 1998, Berkes et al. 2000, Menzies and Butler 2006, Charnley et al. 2007, Uprety et al. 2011, 2012). Traditional Ecological Knowledge is the direct result of a long history of resources being used in an area by indigenous people, where their social structure and belief systems are essential (Berkes et al. 2000, Menzies and Butler 2006, Berkes 2008). Therefore, TEK can complement, supplement, and guide ecological restoration and resource management decisionmaking through the establishment of "reference communities," the design and planning of restoration actions, the selection of suitable species, and monitoring the success of these strategies (Menzies and Butler 2006, Charnley et al. 2007, Parrota and Agnoletti 2007, Uprety et al. 2012, 2017). The integration of TEK in restoration practice is still very limited (Uprety et al. 2012). However, local communities' involvement is fundamental, particularly in those regions where culture and nature are intertwined, which is typically the case with indigenous societies (Garibaldi and Turner 2004, Uprety et al. 2012).
In Mexico, there is a high correlation between biological and cultural diversity (Toledo et al. 2003). It has also been documented that under these conditions, agroforestry systems based on TEK favor cultural landscape preservation, and enable biodiversity conservation. Additionally, such systems are socioeconomically sustainable (Toledo et al. 2003, Falkowski et al. 2016). Within these cultural landscapes, different ecogeographic units can be distinguished. These landscapes are defined by the physical environment, the multiple land uses and management strategies applied, and production practices (Toledo and Barrera-Bassols 2008). For instance, the Totonac from northern Puebla and Veracruz classified five distinct landscape units that referred to the different land uses and productive practices, namely: Kalnekjkakiwin $=$ conserved forest, Kaxánatni $=$ vanilla plantations, milpa, Kiljti = maize orchard, $s a^{\prime} k a t=$ pasture, and k'makjataman = secondary forest. (Toledo et al. 2003). In addition, there is evidence that the composition of conserved forests has been enriched with useful species by ancient Totonac people to produce diversified agroforestry systems that maintain a high diversity of plant species (Gómez-Pompa 1966a, del Amo et al. 2010).

Today, the Totonac face unprecedented social, political, economic, and ecological challenges. Over the past 70 years, the landscape of what used to be their territory has gone through significant changes, which has brought about strong conflicts over land possession (Rodríguez-Luna et al. 2011). Large forested areas deteriorated rapidly, with the consequent erosion of the Totonacs' cultural values and traditional livelihoods (Ianni et al. 2014, Contreras et al. 2015). The degradation of natural systems

${ }^{1}$ Centro de Investigaciones Tropicales, Universidad Veracruzana, ${ }^{2}$ Instituto de Ecología A. C., Red de Biología Evolutiva, ${ }^{3}$ Instituto Nacional de Antropología e Historia, Zona Arqueológica El Tajín 
in Totonac territory has in turn led to the loss of culturally important plant species such as the "palo volador" (Spanish), or Tsaqat Kiwi (Totonac) (Zuelania guidonia (Sw.) Britton \& Millsp., Salicaceae), whose populations have decreased considerably over the last decades (Plan de Salvaguarda 2009). This tree is at the center of the traditional ritual of the Voladores, which was declared an Intangible Cultural Heritage of Humanity by UNESCO in 2010. The ritual ceremony of Los Voladores ("the flying men") is a fertility dance that expresses respect for and harmony with the natural and spiritual worlds. In this ceremony, four young men climb a pole made of a $Z$. guidonia trunk, freshly cut from the forest, and ask for forgiveness from the god of the forest, Kwikgolo. A fifth man, the Caporal, stands on a platform atop the pole and plays songs to the sun. The others fling themselves off the platform "into the void," tied to the platform with ropes (Fig. 1). Fertility is represented by the descent of the Voladores, which symbolizes rain (UNESCO 2017). This ritual gives identity to the Totonac communities from the municipality of Papantla (Trejo 2012), even more since it became an Intangible Cultural Heritage. Given the fact that Z. guidonia populations have greatly diminished, Totonac leaders, with the advice and support of archaeologists and anthropologists working in the region, have devised a safeguard plan to preserve the habitat and natural populations of $Z$. guidonia, which includes both natural and cultural dimensions (Ianni et al. 2014, Silva-Rivera and Velázquez-Rosas 2014). The Voladores' leaders contacted the University of Veracruz research team asking for advice, with a particular interest in recovering Tsaqat Kiwi (Z. guidonia) trees. This represents a unique opportunity to integrate TEK into a restoration strategy. This study evaluated the current state of $Z$. guidonia populations in the vegetation remnants from El Tajín archaeological site, and proposed a restoration strategy that was guided by the principles of traditional agroforestry systems that are still present in the collective Totonac memory. The long-term aim is to recover $Z$. guidonia populations. The study objectives were (1) to quantitatively assess the composition, abundance, and importance value of $Z$. guidonia in vegetation remnants (secondary forest and conserved forest), (2) to determine the accompanying species, their uses, and their regeneration strategy (pioneers, tolerant, and nomads), and (3) to codesign a restoration strategy that integrates Totonac TEK into a context-specific Palo volador agroforestry system model.

\section{METHODS}

\section{Study site}

The study was conducted within El Tajín, an important cosmopolitan, pre-Hispanic Ceremonial Centre, which in 1992 was declared a World Heritage Site by UNESCO (UNESCO $2017)$ and is located in northern Veracruz, Mexico (20²8'35" N, $97^{\circ} 22^{\prime} 39^{\prime \prime} \mathrm{W}$ ), in the municipality of Papantla (INAH 2008). As per Mexican policies for preserving and spreading the nation's cultural richness, 16 years ago, the government decreed El Tajín an archaeological monument zone (DOF 2001), which currently comprises 1221 ha. In the past, the El Tajín metropolis reached its cultural and political peak between 800 and 1200 BC. The climate is of the warm humid, subhumid type with rains in summer and autumn. The average annual temperature and precipitation are $24^{\circ} \mathrm{C}$ and $1160.4 \mathrm{~mm}$, respectively (RodríguezLuna et al. 2011). In the El Tajín polygonal area, livestock production and crop cultivation are the main land uses ( $87.2 \%$ of the total area). Vegetation is represented by fragments of secondary and tropical medium subevergreen forest (12.8\%) (Fig. 2). Regarding land tenure, $83 \%$ is private and communal property; however, there is no clear delimitation of communal lands. The remaining $17 \%$ is federal property. Despite being the smallest percentage, federal property is particularly relevant from an economic viewpoint because access to this area is controlled by the National Institute of Anthropology and History for tourism, education, and research purposes (INAH 2008).

Fig. 1. Ritual ceremony of the Voladores in Papantla, Mexico.

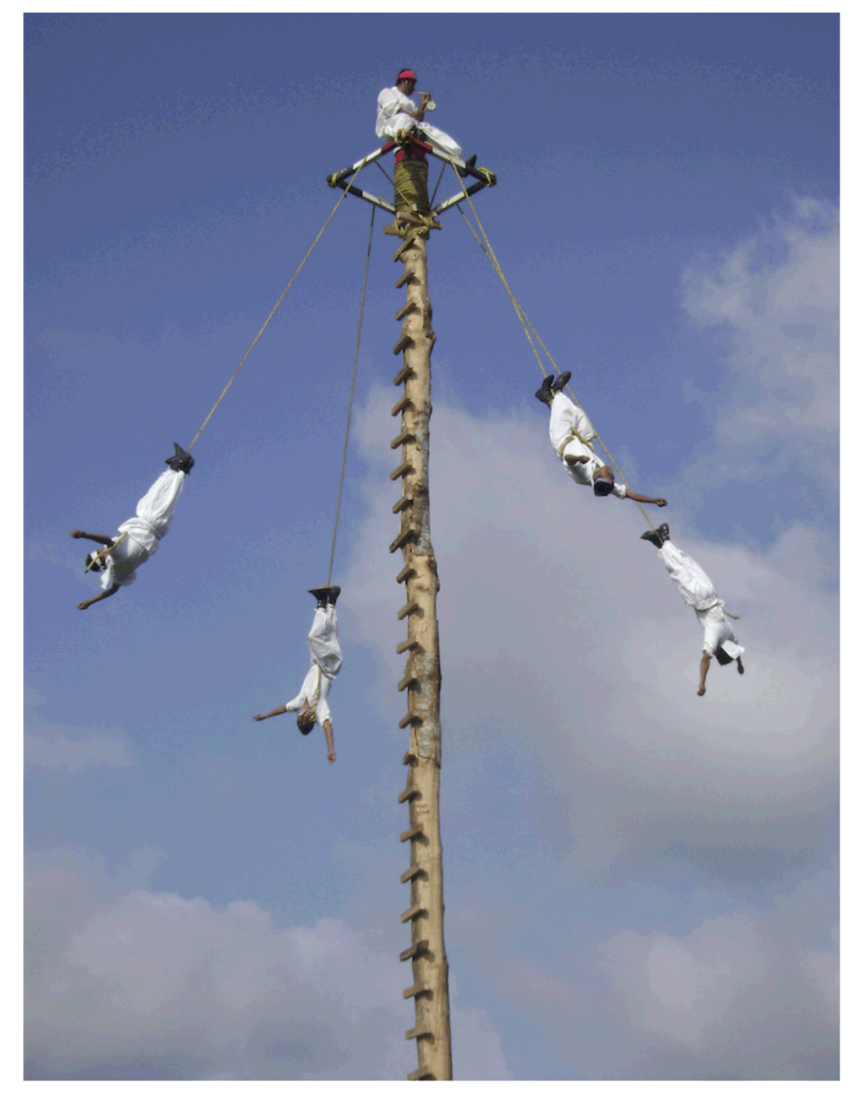

The Totonac community

The tutunaku or Totonac are an ethnic group that currently is distributed in three Mexican states: Hidalgo, Puebla, and Veracruz. About 54\% live in Veracruz, mainly in the Papantla municipality (Chenaut 2010). To an extent, resources are managed traditionally and used in accordance with the sacred value that the Totonac attribute to nature (Chenaut 2010). Another highly relevant cultural element in the Totonac culture is the Los Voladores ritual. This distinctive cultural feature entails a series of purification, healing, and consecration rituals (CrodaLeón 2005). As in many rural areas in Mexico, the Totonac people traditionally practiced subsistence agriculture (maize, beans, and chili peppers). Other important crops were vanilla (Vanilla planifolia Jacks. ex Andrews), precious woods, gum, and tobacco (Chenaut 2010). Although historical records on vanilla cultivation are scarce, it could be said that the vanilla industry in 
Fig. 2. Study area: El Tajín Archaeological Monument Zone, Veracruz, Mexico.

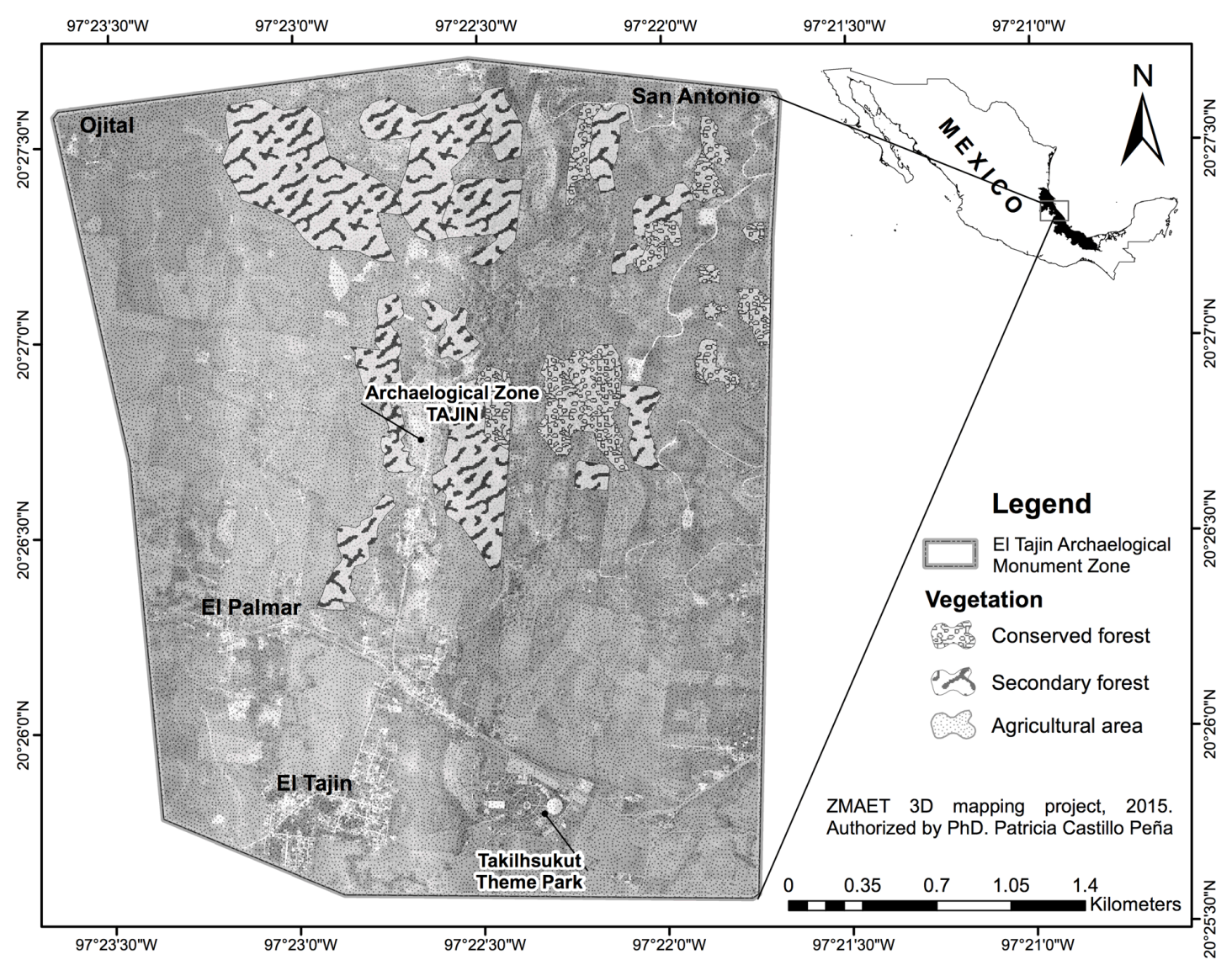

Mexico began around the beginning of 19th century, and the first commercial plantations were established in the rise of the 20th century (Kourí 2013). Vanilla cultivation brought about economic prosperity in the region for more than a century. Vanilla was grown and globally traded from the 19th century until the mid-20th century, when production decreased because of a decline in international prices as synthetic flavors gradually replaced natural vanilla. Moreover, other countries began to successfully produce vanilla (Chenaut 2010, Barrera-Rodríguez et al. 2011). From the mid-20th century, the region experienced a dramatic change in land use, mainly because the oil industry expanded and livestock activity increased. Pastures and monoculture areas, primarily citrus crops, gradually replaced forested areas (Rodríguez-Luna et al. 2011, Ianni et al. 2014). Today, the most productive activities are subsistence and commercial agriculture and livestock production. The latter comprises the largest area, and $6 \%$ of the population is dedicated to this activity. In contrast, traditional agriculture is practiced in very limited areas, even though the number of people dedicated to this activity represents $29 \%$ of the population (INAH 2016) (Fig. 2). Five communities live within the limits of the El Tajín polygon (El Tajín, San Antonio Ojital, Nuevo Ojital, San Lorenzo Tajín, and Zapotal), and comprise 4950 members. Most are indigenous Totonac (87\%) and the rest are mestizos (INAH 2016).
Abundance of Zuelania guidonia and plant species composition To evaluate the abundance of $Z$. guidonia and vegetation composition, we considered two elements of the Totonac cultural landscape classification: secondary forest (k'makjataman, acahual), referring to areas with 5 to 10 years of abandonment; and those that have not been deforested within the last 30 years (Kalnekjkakiwin, hereafter referred to as conserved forest) (Fig. 2). Sampling was restricted to secondary forest and conserved forest because most of the tree species are found in these areas. Sampling in these forests is relevant because it allows for the recording of which resources the forests provide, and the determination of the native seed sources with potential to be used in agroforestry systems.

In secondary forest, fourteen $50 \times 2$-m transects were established with a spacing of $20 \mathrm{~m}$ apart. Because conserved forest in the polygon occurs in a reduced area, 10 transects were established. In each transect, we recorded the abundance of all woody individuals by measuring their diameter at breast height ([DBH] $1.3 \mathrm{~m}$ from the ground) $\geq 2.5 \mathrm{~cm}$. All plants were identified to the species level and classified according to their plant regeneration mode as "light-demanding," "shade-tolerant," or "nomadic" (i.e., species than can grow in both shade and light) (Martínez-Ramos 1985, Ibarra-Manriquez and CornejoTenorio 2010). 
To evaluate whether the sampling was representative, we used the parametric estimator Chao 1. Diversity was calculated using the Shannon Index $\left(\mathrm{H}^{\prime}=-p_{i} \ln p_{i}\right.$, where $p_{i}$ is the relative abundance of the $i$ th species compared with all species identified in a sample), and evenness was calculated with Pieulo's index (J) (Magurran and McGill 2013). To evaluate similarity in plant composition between forests, we used the Jaccard index (Magurran and McGill 2013). All statistical analyses were made using the program EstimateS 9.1 (Coldwell 2013).

The relative importance value in each forest category was calculated as $I_{i}=R F_{i}+R A_{i}+R B A_{i}$, where $R F_{i}$, the relative frequency of the ith species, is the proportion of transects where the ith species was present, divided by the sum of all species frequency, multiplied by $100 ; \mathrm{RA}_{i}$, the relative abundance of the ith species, is the number of individuals of the ith species in all transects multiplied by 100 ; and $\mathrm{RBA}_{\mathrm{i}}$, the relative basal area of the ith species, is the sum of the area (estimated by DBH) of all stems of the ith species in all transects multiplied by 100 (Mostacedo and Fredericksen 2000). Plant uses were determined by local people and corroborated in the literature (Gómez-Pompa 1966b, Ambrosio-Montoya and Avendaño 1999). Frequency of plant use was compared between the different forest categories through a generalized linear model, using a Poisson distribution and a log link function (R Development Core Team 2016). Both vegetation sampling and plant uses identification were carried out collaboratively with local community representatives (knowledgeable campesinos that were born and raised in the study area).

\section{Ecological restoration of Tsaqat Kiwi (Zuelania guidonia), and} codesigning a Totonac agroforestry system

Between May 2012 and March 2013, we conducted five collaborative workshops with the following objectives: (1) to codevelop a strategy to recover populations of $Z$. guidonia through agroforestry systems, (2) to study the environmental conditions in which $Z$. guidonia grows, (3) to codesign the most culturally and ecologically suitable elements of an agroforestry system model, (4) to apply a SWOT analysis to identify the strengths, weaknesses, opportunities, and threats that the organization needed to overcome to restore the Tsaqat Kiwi tree population in the area, and (5) to define potential sites for developing the proposed activities in a restoration strategy. Our local project collaborators were all men, between the ages of 40 and 65 years. They were chosen to participate by the council from the Protection and Preservation of the Ritual Ceremony (hereafter referred to as the council) in what their members named the "Palo Volador Reforestation Project." Almost all dancers were Totonac (90\%), and most of them lived in Poza Rica and Papantla municipalities. The Voladores council coordinates the plan for safeguarding the Voladores' dance to "... ensure the comprehensive conservation of the natural and cultural heritage of this tradition" (Plan de Salvaguarda 2009). The council also administers and makes the decisions concerning the school of Niños Voladores. Children and youngsters attend the school, where they can begin their training from as young as 8-9 years old. The Totonac tradition dictates that the ritual Dance of the Flyers should be executed only by men (Trejo 2012). The teachers function as mentors: their mission is to educate the younger generations to understand and appreciate the symbolic and spiritual meaning of the ritual. For these reasons, teachers have a very important role in their communities and in the organization. Therefore, they often participate in other activities that the organization considers should involve the young. Ten members of the council took part in the collaborative sessions; their responsibility was to follow up on the Plan de Salvaguarda (The Voladores' Ritual Safeguard Plan). The participants were the president, the school of Niños Voladores' teacher, and a representative of the youth. There were also other local community representatives, all men over 40 years old.

The collaborative workshops were designed following a timeflexible structure that included discussion groups and hands-on activities like map drawing and storytelling. Through brainstorming ideas, participants recalled how the landscape used to be in the past (e.g., the 1960s), how it is today, and how they imagined their communities and the archaeological site would look 10 years into the future (Fig. 3). On various occasions, they made lists of the local flora used for different purposes: for food, as medicine, for rituals, and for making houses and hedgerows. One list included all the plant species that grow near or around $Z$. guidonia. Field walks were also an important part of the project because they allowed both Totonac partners and researchers to exchange information and to learn from each other.

Fig. 3. Vision of the council members of how the landscape used to be in the past (a), how it is today (b), and how they imagined their communities and the archaeological site would look 10 years into the future (c).

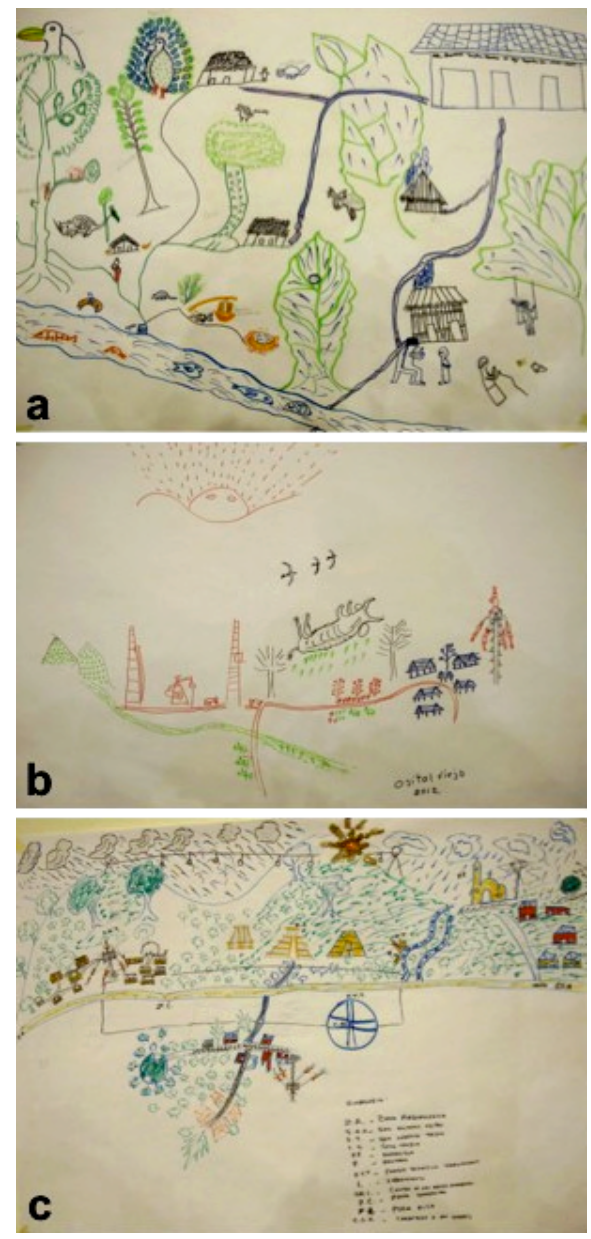


Throughout the analysis, we deliberately refer to "collaborative research," a framework that helps describe the Voladores' project experience. Collaborative research has been defined basically as an "umbrella term for methodologies that actively engage communities and policy makers in the research process from start to finish (Center for Collaborative Research for an Equitable California 2010)," and as research that "merges scientific methods and management planning developed through lasting and dynamic stakeholder collaboration" (Caudron et al. 2012:753). The following lines contextualize how this collaboration took place.

Most of the information related to local social organization was collected qualitatively, with the added advantage that the council had a keen interest in being involved in all stages of the proposed project. This inherent openness was a determinant for the outcomes derived from the experience. There was an exchange of scientific and traditional knowledge with the common goal to recover $Z$. guidonia populations. During the collaborative workshops, focus groups, field walks, and other opportunities where the research team interacted with project participants, general information about some of the flyers' most pressing concerns was discussed: for example, land tenure issues and the need for more effective communication within and with other social and political actors outside the organization. Participants also projected scenarios and discussed different ideas on how to connect with key individuals and institutions that could contribute to the project's organizational and financial development. Also - during the workshops - important information was gathered. The participants explained where $Z$. guidonia seeds could be found, and named the tree's associated species. Propagation mechanisms were discussed too. These data would later contribute to the proposed agroforestry model. Our social research methods combined a predominantly ethnographic approach with ecological restoration methods over almost a year (McCall and Simmons 1969).

Field diaries, as well as written and some audiovisual records of group agreements and conclusions, were kept. Information was classified into three main categories: (a) ethnoecological contents (plant species lists, their uses and cultural values), (b) historical contents (dates, landmark events, main political figures), and the organization's plans and aspirations. The time dimension and reflections on how and why the landscape has changed were recurrent themes. The data used in this study refer specifically to the ethnoecological contents and the organization's plans and aspirations, which were the grounds for the model devised by the research team.

\section{RESULTS}

Abundance of Zuelania guidonia and plant species composition Both the abundance and importance value of $Z$. guidonia in the studied forest were low. In the secondary forest, we recorded 7 individuals per hectare, while in the conserved forest 40 individuals per hectare were recorded. The importance value was 0.71 and 2.45 in the secondary forest and conserved forest, respectively. A notable observation is that most of the trees were juvenile individuals of $Z$. guidonia $(\mathrm{DBH}<10 \mathrm{~cm})$.

We recorded 116 woody species belonging to 35 families. The families with the greatest number of species were Leguminosae
(16), followed by Euphorbiaceae, Lauraceae, and Rubiaceae (with 8 species each). Sixty-six of the 116 species recorded were in the conserved forest, and 58 species were in secondary forest. Ten morphospecies across both sites could not be determined (5 in each type of forest). In both forests, more than $80 \%$ of the species estimated by Chao 1 were registered, which suggested that our sampling was appropriate. Both plant diversity and evenness were higher in the conserved forest (Table 1). According to the Jaccard index, the conserved forest and secondary forest shared $14 \%$ of the species ( 25 species). Density of plants and basal area were higher in the conserved forest (Table 1). Species with the highest importance value in the conserved forest were Bursera simaruba, Brosimum alicastrum, Protium copal, Pimienta dioica, and Cocoloba montana. Together, these species comprised $33 \%$ of the total importance value recorded in conserved forest (Fig. 4a). In secondary forest, the most important species were Guazuma ulmifolia, Adelia barbinervis, Bursera simaruba, Cedrela odorata, and Pisonia acuelata, which together account for $43 \%$ of the total importance value for these forests (Fig. 4b).

Table 1. Diversity $\left(\mathrm{H}^{\prime}=\right.$ Shannon index, $\mathrm{J}=$ Pieulo's index $)$ and structural traits of vegetation at the El Tajín Archaeological Monument Zone, Mexico.

\begin{tabular}{lcccccc}
\hline \hline Forest type & $\begin{array}{c}\text { Plant } \\
\text { species } \\
\text { richness }\end{array}$ & Chao 1 & $\mathrm{H}^{\prime}$ & $\mathrm{J}$ & $\begin{array}{c}\text { Basal area } \\
\left(\mathrm{m}^{2} \mathrm{ha}^{-1}\right)\end{array}$ & $\begin{array}{c}\text { Density } \\
\text { (number of } \\
\text { individuals per } \\
\text { hectare })\end{array}$ \\
\hline $\begin{array}{l}\text { Secondary } \\
\text { forest } \\
\begin{array}{l}\text { Conserved } \\
\text { forest }\end{array}\end{array}$ & 58 & 63 & 2.9 & 0.8 & 27.2 & 3829 \\
\hline
\end{tabular}

Plant uses were accounted for 86 species in both sites, representing $74 \%$ of the total number of woody plant species identified. It should be mentioned that local people use both forest types for the extraction of goods, but the intensity of use is higher in secondary forests. Plant uses were grouped into nine categories (building construction, crafts and tools, food, forage, fuel wood, live fencing, medicinal, timber, and ritual/ornamental). There were significant differences among uses $\left(\chi^{2}=26.12\right.$, df $=8, P<$ 0.0001) (Fig. 5). Medicinal, fuel wood, and live fencing were the most frequent in both forests (Fig. 5). By comparison, neither forest nor interaction term (forest $\times$ uses) differed significantly $\left(\chi^{2}=3.57, \mathrm{df}=8, P=0.941, \chi^{2}=4.053, \mathrm{df}=8, P=0.147\right.$, respectively).

\section{Integrating Traditional Ecological Knowledge into the development of Tsaqat Kiwi (Zuelania guidonia) ecological restoration strategy}

The most relevant social and ecological outcomes from the workshops and other collaborative exchanges were integrated into the agroforestry model. The central idea consists of enhancing the key role of traditional vanilla plantations as a viable means to recover Z. guidonia populations. The Tsaqat Kiwi ecological restoration strategy holds two main components. The first relates to social organization, the creation of alliances, and expanding networks with other social actors in the region (including government authorities and organizations: municipal authorities, National Institute of Anthropology and History [INAH], and 
NGOs, among others). The second is focused on the establishment of agroforestry systems (Table 2). The strategic actions agreed upon during the first stage were (a) the active involvement of the council and its members in the land use planning for the El Tajín polygon to prevent the conversion of the remaining forested fragments to livestock cultivation, monocultures, and urban areas, (b) the implementation of a strategic financial plan that would allow the organization and its members to generate funding and negotiate the donation of municipal lands for establishing a demonstration plot of the previously codesigned agroforestry system, (c) the development of an educational program on traditional plants management, and (d) collaboration with other researchers and advisors that could provide support in planning, administration, and the longer-term implementation facets of the strategy (Table 2).

Fig. 4. Relative importance values for trees in the conserved (a) and secondary forest (b) areas in El Tajín, Veracruz. Ab: Adelia barbinervis, Ba: Brosimum alicastrum, Bs: Bursera simaruba, Cg: Cupania glabra, Co: Cedrela odorata, Cm: Coccoloba montana, Cv: Chione venosa var. mexicana, Ec: Eugenia capuli, Gu: Guazuma ulmifolia, Ns: Nectandra salicifolia, Pa: Pisonia aculeta, Pac: Parmentiera aculeata, Pb: Prunus brachybotrya, Pc: Protium copal, Pd: Piminenta dioica, Ta: Tabernaemontana alba, and Tm: Talasia macrophylla.
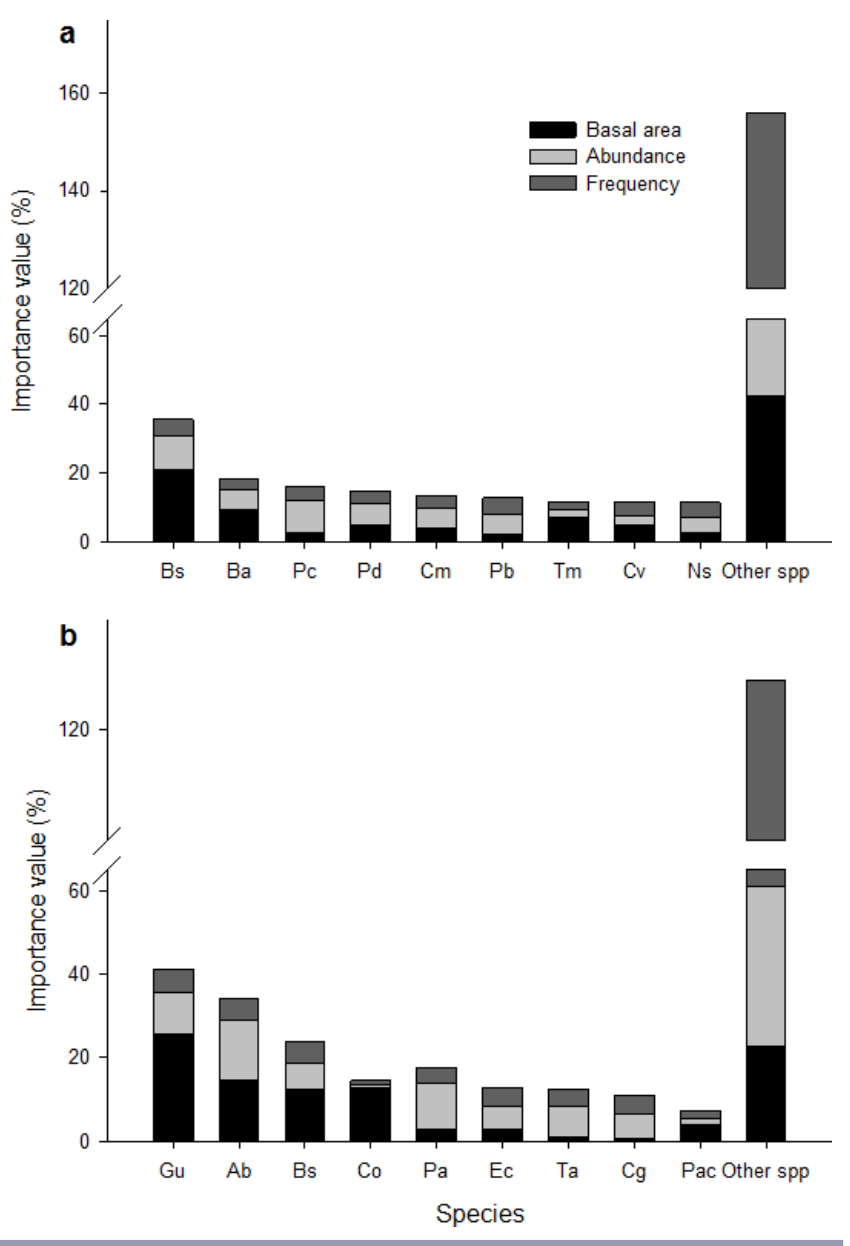

Fig. 5. Plant species uses in the conserved (black bar) and secondary (gray bar) forests in El Tajín, Veracruz. C: crafts and tools, LF: live fencing, R: ritual and ornamental, FO: forage, FW: fuelwood, M: medicinal, T: timber, BC: building construction, and $\mathrm{F}$ : food. Letters indicate significant differences between uses $(P<0.05)$.

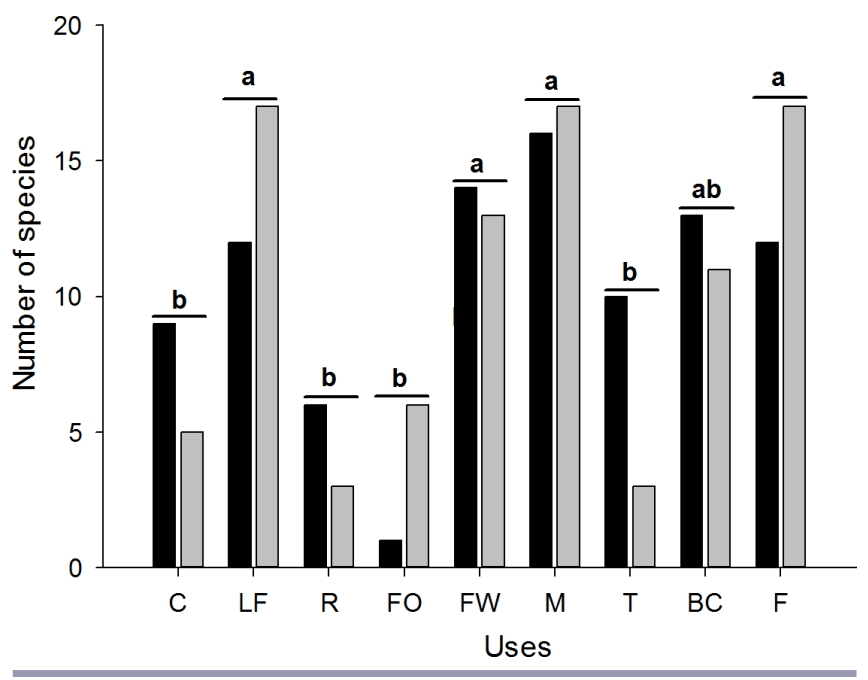

Agroforestry system

The workshops lasted between one and two days, with work sessions held in the archaeological site's auditorium, combined with visits and field walks to nearby plots. Data were gathered seeking triangulation between methods. Short videos and a photographic record were taken. During collective activities, agreements were written down on large sheets of paper that everyone could see. This was the case of the SWOT analysis and plant lists. Schematic drawings were made of an ideal Zuelania guidonia agroforestry system and its associated plant and tree species. The Voladores also described, discussed, and drew what their communities were like in the past, how they see them in the present, and how they would like the Tajín region to be in the future (Fig. 3). They reflected on how and why the land has changed over the past five decades. Relevant, complementary data collected during field walks were noted in field journals. Information included lists of species and their uses, local historical events, political problems within and outside the group, and anecdotes on their performance of the ritual as a tourist attraction in other parts of Mexico and overseas. It is important to stress that the research process occurred at the same time that project activities took place, and in an amicable mutual learning atmosphere.

The resulting diversified agroforestry hybrid model that included Totonac TEK and scientific-based information was presented to the organization board members several months after, when the project had concluded. This piece of research represents the following stage: a more detailed study that demonstrates that the Voladores identified vanilla plantations as the best agroforestry system for the recovery of Z. guidonia populations, and for the provision of local people's basic needs in vastly transformed landscapes. 
Table 2. Strategic plan developed with the Voladores' council, to recover Zuelania guidonia populations in the El Tajín archaeological site (Papantla, Veracruz, Mexico).

\begin{tabular}{|c|c|c|}
\hline Strategy & Topics & Actions \\
\hline \multicolumn{3}{|l|}{ Social organization } \\
\hline & Territorial organization & $\begin{array}{l}\text { To negotiate the council's intervention in all decisions related to El Tajín's territorial } \\
\text { planning. Official requests to local and federal government institutions (Instituo }\end{array}$ \\
\hline & Financial plan & $\begin{array}{l}\text { Collaborative workshops and strategic planning. Outcomes: concluded funding } \\
\text { proposals ready to be submitted to different governmental and nongovernmental } \\
\text { organizations and foundations }\end{array}$ \\
\hline & Educational program & $\begin{array}{l}\text { To encourage various knowledge exchange activities among elders, healers, children, } \\
\text { and herbalists to preserve Traditional Ecological Knowledge by using the campesino } \\
\text { a campesino technique }\end{array}$ \\
\hline & $\begin{array}{l}\text { Collaborative alliances with } \\
\text { academic institutions and } \\
\text { organizations }\end{array}$ & $\begin{array}{l}\text { To establish agreements with ecologists and other conservation and sustainability/ } \\
\text { sustainable development specialists and institutions }\end{array}$ \\
\hline \multirow[t]{5}{*}{ Agroforestry system } & Traditional vanilla plantations & Seed collection from selected tree species in vegetation remnants \\
\hline & & Seedling production in nursery \\
\hline & & Planting of light-demanding species \\
\hline & & Planting of shade-tolerant species \\
\hline & & Vanilla cultivation \\
\hline
\end{tabular}

Bearing in mind that Z. guidonia is a light-demanding species, the council determined that the best sites to successfully grow it are those with stony soils and high solar radiation incidence. The selected agroforestry system was a traditionally managed vanilla plantation. Aside from the region's history of vanilla production and international trade, there are other fundamental reasons for this selection: a vanilla plantation can be developed in a secondary forest, it allows other useful species to grow, and more importantly, the implementation costs are low compared with technified vanilla production systems (intensified greenhouse production, with irrigation systems and agrochemical use). In addition to $Z$. guidonia, 22 useful species that grow in secondary forest were chosen. Twenty-one of those were trees and native palms, and only one introduced species was included (Mangifera indica) (Table 3); 50\% of the selected species are used for fuel wood and construction (Table 3). Light-demanding species make up $73 \%$, and $23 \%$ are shade-tolerant. The sites chosen to begin the demonstration plot were pastures, abandoned oil wells, and deforested areas, all located within the El Tajín archaeological site. It was estimated collaboratively that a fully grown Tsaqat Kiwi agroforestry system could be established in 5 years. During the first 3 years, actions will be focused on growing lightdemanding species, which include $Z$. guidonia, followed by shade-tolerant species. Finally, when conditions are favorable enough (i.e., a full-grown canopy has been achieved), the traditional vanilla plantation can be introduced and cared for (Table 2).

In 2014, after a series of negotiations, the municipal authority donated a 2-ha plot to the Voladores' council. The area consisted of a small forested patch, a milpa, that used to be rented occasionally by landless campesinos. The remainder was secondary forest; advised by the researchers, the Voladores actively engaged in preparing the land and planting selected native tree species. First, through a faena (an ancient practice where local indigenous and mestizo campesinos work voluntarily for the benefit of their communities), they applied a selected pruning method in which shrubs were eliminated and native plants and bushes were left. Supervised by the university research team, the Voladores collected hundreds of Z. guidonia seeds. The result was 5000 Tsaqt Kiwi tree individuals. These plants were donated to local schools $(80 \%)$, and the remaining ones were planted in the demonstration plot.

\section{DISCUSSION}

In this study, we reported a low abundance of Z. guidonia in El Tajín's vegetation remnants. In addition, the recorded individuals were juveniles and would not have been suitable for the Voladores' ritual. However, secondary and conserved forests retain high plant species richness, which can provide complementary resources. These plants are also the source of needed propagules to cultivate vanilla pods and to enrich the agroforestry system that could help the recovery of $Z$. guidonia populations.

Traditional ecological knowledge integrates local practices, social structures, and beliefs about the relationship between humans, local ecosystems, and culture (Berkes 2008). Concurrently, in this study, the vanilla plantation design included both modern knowledge and the Totonac people's knowledge of the use of native and locally found plants, the revitalization of a culturally important tree species, Tsaqat Kiwi, and the recuperation of an ancestral crop (vanilla). In the long term, this codesigned model has the potential to introduce a heterogeneous landscape management with many advantages. The Tsaqat Kiwi agroforestry system will provide food and medicine. It also reinforces local identity, and in the context of modernization, it represents a deep spiritual connection with the land, while favoring biodiversity conservation and providing ecological services (Toledo et al. 2003, del Amo et al. 2010). Our data show the importance of respecting and accounting for local ecological knowledge in the design of biocultural landscape restoration strategies, not only because indigenous groups have historically been silenced and denied the right to decide over their territory (Toledo 2014). Another powerful reason is that the dominant Western science paradigm has recently begun to recognize the value of other forms of 
Table 3. Species designed for the integration of agro-ecosystems (vanilla production) associated with Zuelania guidonia. Uses: BC: building construction, C: crafts and tools, F: food, FW: fuelwood, LF: live fencing, M: medicinal, R: ritual and ornamental, and T: timber. Regeneration mode (RM): shade-tolerant (ST), light-demanding (LD), and nomads (N). * exotic species.

\begin{tabular}{|c|c|c|c|c|}
\hline Family & Species & Common name & Uses & RM \\
\hline Anacardiaceae & Mangifera indica $\mathrm{L} . *$ & Mango & $\mathrm{F}, \mathrm{FW}$ & LD \\
\hline Araliaceae & Dendropanax arboreus (L.) Decne \& Planch & Palo de agua & $\mathrm{F}, \mathrm{BC}$ & LD \\
\hline Arecaceae & Attalea butyracea (Mutis ex L.f.) Wess- Boer & Palma real & $\mathrm{F}, \mathrm{BC}$ & LD \\
\hline \multirow[t]{2}{*}{ Burseraceae } & Bursera simaruba (L.) Sarg. & Chaca & LF, FW, C & LD \\
\hline & Protium copal (Schltdl. \& Cham.) Engl. & Copalillo & $\mathrm{R}, \mathrm{FW}, \mathrm{T}, \mathrm{BC}$ & ST \\
\hline Cannabaceae & Aphananthe monoica (Hemsl.) J.-F.Leroy & Pipín & $\mathrm{BC}, \mathrm{FW}$ & $\mathrm{N}$ \\
\hline Lauraceae & Nectandra ambigens (S.F. Blake) C.K. Allen & Laurel & $\mathrm{F}$ & $\mathrm{N}$ \\
\hline Leguminosae & Piscidia piscipula (L.) Sarg. & Chijol & $\mathrm{BC}, \mathrm{LF}$ & LD \\
\hline \multirow[t]{2}{*}{ Meliaceae } & Cedrela odorata $\mathrm{L}$. & Cedro & $\mathrm{T}$ & LD \\
\hline & Swietenia macrophylla King & Caoba & $\mathrm{T}$ & $\mathrm{N}$ \\
\hline \multirow[t]{3}{*}{ Malvaceae } & Carpodiptera cubensis Griseb & Alzaprima & $\mathrm{BC}, \mathrm{LF}, \mathrm{FW}$ & LD \\
\hline & Ceiba pentandra (L.) Gaertn & Ceiba & $\mathrm{R}$ & LD \\
\hline & Heliocarpus donnellsmithii Rose & Jonote & FW & LD \\
\hline \multirow[t]{3}{*}{ Moraceae } & Brosimum alicastrum $\mathrm{Sw}$. & Ojite & $\mathrm{BC}, \mathrm{F}$ & ST \\
\hline & Castilla elastica Cerv. & Hule & $\mathrm{C}, \mathrm{FW}, \mathrm{M}$ & LD \\
\hline & Ficus obtusifolia Kunth & Higuera blanca & $\mathrm{LF}$ & LD \\
\hline Myrtaceae & Pimenta dioica (L.) Merr. & Pimienta & $\mathrm{F}$ & $\mathrm{N}$ \\
\hline Poaceae & Guadua angustifolia Kunth & Tarro & $\mathrm{BC}, \mathrm{LF}$ & LD \\
\hline Primulaceae & Myrsine coriacea (Sw.) R.Br. ex Roem. \& Schult. & Escolin & $\mathrm{T}, \mathrm{BC}, \mathrm{FW}$ & LD \\
\hline Sapindaceae & Cupania glabra Sw. & Garrochilla & $\mathrm{FW}, \mathrm{BC}$ & LD \\
\hline Sapotaceae & Pouteria sapota (Jacq.) H. E. Moore \& Stearn & Zapote & $\mathrm{F}$ & $\mathrm{N}$ \\
\hline Verbenaceae & Lippia myriocephala Schltdl. \& Cham. & Tabaquillo & FW & LD \\
\hline
\end{tabular}

knowledge (Bonta et al. 2017) and their epistemic origins. "Indigenous knowledge as a human-environmental wisdom stresses deep connections between people and their spiritual reality" (Grincheva 2013:15). Efforts to bridge Western and indigenous knowledge represent multiple, unexplored opportunities for better understanding of how human societies relate to the environment, and the potential to create alternative paths in times of crisis.

The success of ecological restoration projects depends on the participation of local communities, on an adequate species selection, and on long-term monitoring and maintenance by local communities (Douterlunge and Ferguson 2012, Falkowski et al. 2016). Under these conditions, the Voladores' collective idea of an agroforestry system suitable to their current socio-cultural and productive needs, where the Tsaqat Kiwi tree is at the center, is a traditionally managed vanilla plantation. Species were selected based on their usefulness and ability to grow in open sites $(100 \%$ are useful and $73 \%$ are light-demanding species). The use of lightdemanding species for reforestation of pastures or abandoned oil wells would favor the establishment and development of secondary vegetation. This selection of species differs from that adopted in many official reforestation programs in which primary shade-tolerant species have been chosen and unsuccessfully introduced (UACH 2010). Programs that garner local people's support through collaborative experiences have a greater chance of adoption and therefore an increased likelihood of achieving long-term sustainability (Danielsen et al. 2005).

Historically, vanilla plantations have played a pivotal role that has defined the Totonac landscape for centuries. Traditional vanilla cultivation has had its ups and downs throughout history. In its most recent stage, vanilla plantations were abandoned during the 1980s because of a dramatic drop in the price of natural vanilla on the international market (Barrera-Rodriguez et al. 2011). Today, the remaining traditional vanilla plantations are cared for on a reduced scale, and vanilla is generally cultivated under controlled high-tech conditions, namely, in greenhouses. The recent positioning of natural vanilla in the global market has led to an increase in international prices (Barrera-Rodríguez et al. 2011). In this economic context, attention has been directed to what is known about the different vanilla species, their conservation status, and sustainable use. Research studies aiming to improve ecologically sound cultivation techniques have been undertaken (Barrera-Rodríguez et al. 2011). Under these circumstances, collaborative research oriented toward restoring traditional vanilla plantations in deforested areas could be harnessed to strengthen local and regional economies. Some of the advantages of these management regimes favor the use of multipurpose plant species, making them accessible to local families and communities. Forest products from agroforestry systems have an immense potential to cover basic household needs as food, as medicine, as construction materials, and as identity elements that allow the continuation of ancient and significant rituals and ceremonies (Toledo et al. 2003, Juárez-López 2015). This study adds to the body of literature in favor of integrating TEK into forest restoration projects through collaborative research methods as a richer, context-relevant avenue that could help materialize conservation efforts in priority regions with longer term results.

The proposed Tsaqat Kiwi agroforestry system is based fundamentally on the modern Totonac people's TEK. Nevertheless, it is crucial to account for the social and political dynamics that determine the main drivers of change in the regional social-ecological system. These elements altogether can 
contribute to better-informed and economically and socialecologically relevant decision-making processes regarding the use of the territory (Naveh 1998, Olsson and Folke 2001, Charnley et al. 2007). The council asked for technical support from university researchers. During the project, this resulted in a collaborative relationship and key follow-up actions in terms of the development of species propagation protocols and other decisions taken around territorial planning, particularly in the El Tajín archaeological polygon. Actions such as these represent an opportunity to build knowledge dialogues between traditional and scientific knowledge with a common aim of contributing to Totonac biocultural landscape restoration based on the current social-ecological population dynamics while acknowledging and incorporating elements of modernity (Charnley et al. 2007, Davis and Ruddle 2010, del Amo 2011, Hobbs et al. 2011, Uprety et al. 2012, Ruddle and Davis 2013). Our results sum up the growing literature in favor of traditional management practices to recover bioculturally diverse landscapes as viable, highly relevant alternatives in the face of the ongoing planetary social-ecological crisis (Toledo 2014).

\section{CONCLUSION}

This work underlines the importance of integrating TEK in the design of restoration strategies to ensure local communities' livelihoods while biodiversity is sustainably used and conserved. It also stresses the value of studies that engage with developing innovative sustainable landscape planning tools and methods where historically neglected indigenous people, along with their wisdom, expectations and aspirations, should play a fundamental role. The agroforestry system to recover $Z$. guidonia populations, which resulted from the integration of scientific and traditional ecological knowledge, will allow long-term restoration of biocultural landscapes and could potentially impact the conservation of the region's cultural legacy and ecological services.

Responses to this article can be read online at: http://www.ecologyandsociety.org/issues/responses. $\mathrm{php} / 10294$

\section{Acknowledgments:}

The authors are grateful to the Consejo para la Protección $y$ Preservación de la Ceremonia Ritual de Voladores A.C for their time and knowledge. We thank S. Sinaca Colin, Iliana Romero, Luis Cabrera, and XAL Herbarium for providing technical taxonomic support. We also thank two anonymous reviewers whose comments greatly improved this article.

\section{LITERATURE CITED}

Ambrosio-Montoya, M., and S. Avendaño. 1999. Plantas útiles del municipio de Misantla, Veracruz. La Ciencia y el Hombre 31:43-88.

Anderson, M. K., and M. G. Barbour. 2003. Simulated indigenous management: a new model for ecological restoration in national parks. Ecological Restoration 21:269-277. http://dx. doi.org/10.3368/er.21.4.269
Barrera-Rodríguez, A., J. L. Jaramillo-Villanueva, J. S. Escobedo, and B. E. Herrera-Cabrera. 2011. Rentabilidad y competitividad de los sistemas de producción de Vainilla (Vanilla planifolia Jacks. ex Andrews) en la región del Totonacapan, Mexico. Agrociencia 45:625-638. [online] URL: http://www.scielo.org.mx/pdf/agro/ $\mathrm{v} 45 \mathrm{n} 5 / \mathrm{v} 45 \mathrm{n} 5 \mathrm{a} 8 . \mathrm{pdf}$

Berkes, F. 2008. Sacred ecology. Traditional ecological knowledge and resource management. Second edition. Taylor \& Francis, Philadelphia, Pennsylvania, USA.

Berkes, F., J. Colding, and C. Folke. 2000. Rediscovery of traditional ecological knowledge as adaptive management. Ecological Applications 10:1251-1262. http://dx.doi.org/10.1890/1051-0761 (2000)010[1251:ROTEKA]2.0.CO;2

Bonta, M., R. Gosford, D. Eussen, N. Ferguson, E. Loveless, and M. Witwer. 2017. Intentional fire-spreading by "Firehawk" raptors in Northern Australia. Journal of Ethnobiology 37:700-718. http://dx.doi.org/10.2993/0278-0771-37.4.700

Caudron, A., L. Vigier, and A. Champignelle. 2012. Developing collaborative research to improve effectiveness in biodiversity conservation practice. Journal of Applied Ecology 49:753-757. http://dx.doi.org/10.1111/j.1365-2664.2012.02115.x

Center for Collaborative Research for an Equitable California. 2010. What is collaborative research? Scholarship in action. Equity-oriented collaborative community-based research. [online] URL: https://ccrec.ucsc.edu/center/what-collaborativeresearch

Charnley, S., A. Paige Fischer, and E. T. Jones. 2007. Integrating traditional and local ecological knowledge into forest biodiversity conservation in the Pacific Northwest. Forest Ecology and Management 246:14-28. http://dx.doi.org/10.1016/j.foreco.2007.03.047

Chenaut, V. 2010. Los totonacas en Veracruz: población, familia y sociedad. Pages 45-66 in E. Florescano, and J. Ortíz Escamilla, editors. Atlas del Patrimonio natural, histórico y cultural de Veracruz, Patrimonio cultural. Gobierno del Estado de Veracruz, Universidad Veracruzana, Mexico.

Coldwell, R. K. 2013. EstimateS: statistical estimation of species and shared species from samples. Version 9. [online] URL: $\underline{\text { http:// }}$ viceroy.eeb.uconn.edu/estimates/

Contreras, B., E. Silva-Rivera, E. Parraguez, and J. R. Barton. 2015. Gobernanza ambiental en la región de la cordillera Mapuche (Chile) y el Totonacapan (México): conflictos en el acceso y uso del ecosistema. Pages 691-710 in L. C. Ruelas Monjardí, A. C. Travieso Bello, O. M. Sánchez-Sánchez, editors. Gobernanza ambiental: teoría y práctica para la conservación y uso sustentable de los recursos. Plaza y Valdéz, Colegio de Veracruz, Universidad Veracruzana, Mexico.

Covington, W., W. A. Niering, E. Starkey, and J. Walker. 1998. Ecosystem restoration and management: scientific principles and concepts. Human agents of ecological change. Elsevier Publisher.

Croda-León, R. 2005. Entre los Hombres y las Deidades. Las Danzas del Totonacapam. CNCA-Dirección General de Culturas Populares e Indigenas. D. F., México.

Danielsen, F., N. D. Burgess, and A. Balmford. 2005. Monitoring matters: examining the potential of locally-based approaches. 
Biodiversity and Conservation 14:2507-2542. http://dx.doi. org/10.1007/s10531-005-8375-0

Davis, A., and K. Ruddle. 2010. Constructing confidence: rational skepticism and systematic enquiry in local ecological knowledge research. Ecological Applications 20:880-894. http://dx.doi. org/10.1890/09-0422.1

del Amo, S. 2011. El cambio de modelo de desarrollo necesario en un país pluricultural, algunos aspectos que se deben tomar en cuenta. Etnobiología 9:60-78.

del Amo S., M. C. Vergara-Tenorio, J. M. Ramos-Prado, and L. Porter-Bolland. 2010. Community landscape planning for rural areas: a model for biocultural resource management. Society \& Natural Resources 23:436-450. http://dx.doi.org/10.1080/08941920802537781

Diario Oficial de la Federación (DOF). 2001. Decreto por el que se declara zona de monumentos arqueológicos el área conocida como El Tajín, ubicada en el Municipio de Papantla de Olarte, en el Estado de Veracruz. Secretaría de Gobernación. Gobierno de México. 30 de marzo de 2001. [online] URL: http://dof.gob.

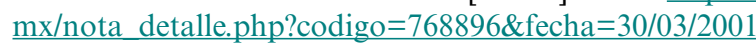

Douterlungne, D., and B. G. Ferguson. 2012. Manual de restauración ecológica campesina para la selva lacandona. First edition. El Colegio de la Frontera Sur, San Cristobal de las Casas, Chiapas, Mexico.

Falkowski, T. B., S. A. W. Diemont, A. Chankin, and D. Douterlungne. 2016. Lacandon Maya traditional ecological knowledge and rainforest restoration: soil fertility beneath six agroforestry system trees. Ecological Engineering 92:210-217. http://dx.doi.org/10.1016/j.ecoleng.2016.03.002

Garibaldi, A., and N. Turner. 2004. Cultural keystone species: implications for ecological conservation and restoration. Ecology and Society 9(3):1. http://dx.doi.org/10.5751/ES-00669-090301

Gómez-Pompa, A. 1966a. Three levels of conservation by local people. Pages 347-356 in F. di Castri and T. Yoúnes, editors. Biodiversity, science and development. CAB international, Wallingford, UK.

Gómez-Pompa, A. 1966b. Estudios botánicos en la región de Misantla, Veracruz. Instituto Mexicano de Recursos Naturales Renovables A. C., D. F., Mexico.

Grincheva, N. 2013. Scientific epistemology versus indigenous epistemology: meanings of 'place' and 'knowledge' in the epistemic cultures. Logos \& Episteme 4:145-159. http://dx.doi. org/10.5840/logos-episteme20134224

Hobbs R. J., L. M. Hallet, P. R. Ehrlich, and H. A. Money. 2011. Intervention ecology: applying ecological science in the twentyfirst century. BioScience 61:442-450. http://dx.doi.org/10.1525/ bio.2011.61.6.6

Ianni, E., E. Silva-Rivera, and D. Geneletti. 2014. Sustaining cultural and biological diversity in rapidly changing communities: the revitalization

of the Voladores ritual in northern Veracruz (Mexico). Environment, Development and Sustainability 16:1197-1208. http://dx.doi.org/10.1007/s10668-014-9520-2
Ibarra-Manríquez, G., and G. Cornejo-Tenorio. 2010. Diversidad de frutos de los árboles del bosque tropical perennifolio de México. Acta Botánica Mexicana 90:51-104. http://dx.doi. org/10.21829/abm90.2010.299

Instituo Nacional de Antropología e Historia (INAH). 2008. Plan de manejo, Zona Arqueológica EL Tajín. Consejo Nacional para la Cultura y las Artes, Instituto Nacional de Antropologia e Historia. Serie: Planeación de Sitios Patrimonio Mundial. Veracruz, Mexico.

Instituo Nacional de Antropología e Historia (INAH). 2016. Plan Maestro para el Desarrollo Social y la Sostenibilidad de la Zona de Monumentos Arqueológicos El Tajín. Instituto Nacional de Antropología e Historia. Veracruz, México.

Juárez-López, B. M. 2015. Cafetales mixes de San José El Paraíso, Oaxaca, Relaciones sociales y Diversidad Arbórea. Thesis. Centro de Investigaciones Tropicales, Universidad Veracruzana. Xalapa, Veracruz, Mexico.

Kourí, E. 2013. Un pueblo dividido. Comercio, propiedad y comunidad en Papantla, México. Fondo de Cultura Económica, El Colegio de México, Mexico.

Magurran, A. E., and B. McGill. 2013. Biological diversity: frontiers in measurement and assessment. Oxford University Press, USA.

Mantyka-Pringle, C. S., T. D. Jardine, L. Bradford, L. Bharadwaj, A. P. Kythreotis, J. Fresque-Baxter. E. Kelly, G. Somers, L, E. Doig, P. D. Jones, K. E. Lindenschmidt, the Slave River, and Delta Partnership. 2017. Bridging science and traditional knowledge to assess cumulative impacts of stressors on ecosystem health. Environmental International 102:125-137. http://dx.doi.org/10.1016/ j.envint.2017.02.008

Martínez-Ramos, M. 1985. Claros, ciclos vitales de los árboles tropicales y regeneración natural de las selvas altas perennifolias. Pages 191-239 in A. Gómez-Pompa and A. del Amo, editors. Investigaciones sobre regeneración de las selvas altas en Veracruz. Vol. II. Alhambra Mexicana, Mexico.

McCall, G. J., and J. L. Simmons. 1969. Issues in participant observation: a text and reader. Addison-Wesley Publishing Company, Boston, Massachusetts, USA.

Menzies, C. R., and C. Butler. 2006. Understanding ecological knowledge. Pages 1-20 in C. R. Menzis, editor. Traditional ecological knowledge and natural resource management. University of Nebraska Press, Lincoln, Nebraska, USA.

Mostacedo, B., and T. S. Fredericksen. 2000. Manual de Métodos Básicos de Muestreo y Análisis de Vegetación en Ecología Vegetal. Bolfor, EL Pais, Santa Cruz, Bolivia.

Naveh, Z. 1998. Ecological and cultural landscape restoration and the cultural evolution towards a post-industrial symbiosis between human society and nature. Restoration Ecology 6:135-143. http://dx.doi.org/10.1111/j.1526-100X.1998.00624.x

Olsson, P., and C. Folke. 2001. Local ecological knowledge and institutional dynamics for ecosystem management: a study of Lake Racken Watershed, Sweden. Ecosystems 4:85-104. http://dx. doi.org/10.1007/s100210000061 
Parrota, J. A., and M. Agnoletti. 2007. Traditional forest knowledge:challenges and opportunities. Forest Ecology and Management 249:1-4. http://dx.doi.org/10.1016/j.foreco.2007.05.022

Plan de Salvaguarda. 2009. Ceremonia de ritual de voladores. Convención para la salvaguarda del Patrimonio cultural inmaterial, UNESCO, Mexico. Gobierno del Estado de Veracruz, Veracruz, Mexico.

Rodríguez-Luna, E., A. Gómez-Pompa, J. C. López Acosta, N. Velázquez-Rosas, Y. Aguilar-Domínguez, and M. TorresVázquez. 2011. Atlas de los espacios naturales protegidos de Veracruz. Gobierno del Estado de Veracruz, Universidad Veracruzana. Veracruz, Mexico.

R Development Core Team. 2016. R: a language and environment for statistical computing. $\mathrm{R}$ Foundation for Statistical Computing. [online] URL: http://www.R-project.org

Ruddle, K., and A. Davis. 2013. Local Ecological Knowledge (LEK) in interdisciplinary research and applications: a critical review. Asian Fisheries Science 26:79-100. [online] URL: https:// www.asianfisheriessociety.org/publication/abstract.php? $\mathrm{id}=968$

Silva-Rivera, E., and N. Velázquez-Rosas. 2014. Hacia la sustentabilidad de la diversidad biocultural en comunidades cambiantes: El proceso de revitalización de los voladores en el norte de Veracruz. Congreso Internacional de Investigaciones Sobre el Mundo Totonaco. Universidad Intercultural del Estado de Puebla, Puebla. 27-29 de Agosto, Mexico.

Toledo, V. 2014. 2050: Crisis de civilización y poder social. Pages 152-161 in A. Bartra, J. Boltvinik, A. Damián, V. Flores Oléa, A. Guillen, C. San Juan, J. Saxe-Fernández, V. Toledo, and L. Arizmendi, editors. Crisis Global y Encrucijadas Civilizatorias. Editorial Ink, Fundación Heberto Castillo Martínez, Ciudad de Mexico, Mexico.

Toledo, V., and N. Barrera-Bassols. 2008. La memoria biocultural. La importancia ecológica de las sabidurías tradicionales. Icaria, Barcelona, Spain.

Toledo, V. M., B. Ortiz-Espejel, L. Cortés, P. Moguel, and M. J. Ordoñes. 2003. The multiple use of tropical forests by indigenous peoples in Mexico: a case of adaptive management. Conservation Ecology 7(3):9. http://dx.doi.org/10.5751/ES-00524-070309

Trejo, J. 2012. Los que Siguen Volando. La Danza de los Voladores entre los Totonacos de Papantla. Thesis. Departamento de Antropología, Universidad Atonónoma Metropolitana, D. F., México.

United Nations Educational, Scientific and Cultural Organization (UNESCO). 2017. Ritual ceremony of the Voladores. [online] URL: https://ich.unesco.org/en/RL/ritualceremony-of-the-voladores-00175

Universidad Autónoma de Chapingo (UACH). 2010. Informe de evaluación externa de los apoyos de reforestación, ejercicio fiscal 2009. SEMARNAT, CONAFOR, Mexico.

Uprety, Y., H. Asselin, and Y. Bergeron. 2017. Preserving ecosystem services on indigenous territory through restoration and management of a cultural keystone species. Forest 8:194. $\underline{\text { http://dx.doi.org/10.3390/f8060194 }}$
Uprety, Y., H. Asselin, Y. Bergeron, F. Doyon, and J.-F. Boucher. 2012. Contributions of traditional knowledge to ecological restoration: practices and applications. Ecoscience 19:225-237. http://dx.doi.org/10.2980/19-3-3530

Uprety, Y., R. C. Poudel, H. Asselin, and E. Boon. 2011. Plant biodiversity and ethnobotany inside the projected impact area of the Upper Seti Hydropower Project, Western Nepal. Environment, Development and Sustainability 13:463-492. http://dx.doi. org/10.1007/s10668-010-9271-7 